\title{
The Influences of Facebook on High School Students' Pattern of Social Life: The Case of Harar City
}

\author{
Dame Dereba Shoa ${ }^{*}$ and Gutema Imana Keno ${ }^{2}$ \\ ${ }^{1,2}$ Department of Sociology, College of Social Sciences and Humanities Haramaya \\ University, Ethiopia \\ Haramaya, Oromia, Ethiopia \\ Email: damedereba@gmail.com \\ Email: gimanke@yahoo.com
}

\begin{abstract}
In today's world, it seems that social media and youngsters are destined for each other as both are young, fast paced and ever changing. It has become very challenging to cultivate and socialize youngsters with patterned social norms due to the influences of media like television and Facebook. Educators are challenged more seriously than ever before to teach youngster, as students are using Facebook at school and home. The aim of this study was to investigate the multifaceted influences of Facebook on youth's pattern of social life. Both quantitative and qualitative methods of data collection were employed to collect the data. Questionnaire, interview schedule and key informant interviews were data collection tools used to collect the quatitative and qualitative data respectively. The study founded that, Facebook is a social medium that discourages social bond in one way and encourages in the other way. By networking peers online, it enhances strong affiliation among Facebook friends while by letting them ignore people who are nearby, it debilitates face to face to face personal interactions. Anonymous Facebook users can meet in 'chat rooms' and discuss on topics of their choices with the person they do not know before and this type of electronic friendship and interaction may grow up and leads to virtual physical face-to-face contacts. Facebook is therefore, a platform for youths to discuss and interact on the issues of mutual curiosity which could enhance and promote synchronization of friends on the one side and inflammatory rhetoric conflicts on the other side, which implies the inevitable and multidimensional influences of Facebook on the youth's social life.
\end{abstract}

Keywords: facebook, interaction, social life

\begin{abstract}
Abstrak
Saat ini, tampaknya media sosial dan anak muda adalah dua hal yang sangat berkaitan, karena keduanya kekinian, cepat dan selalu berubah. Menjadi sangat sulit untuk menumbuhkan norma sosial kepada anak muda karena pengaruh media seperti televisi dan Facebook. Pendidik ditantang lebih serius daripada masa sebelumnya untuk mengajar anak muda, karena siswa menggunakan Facebook di sekolah dan di rumah. Tujuan dari penelitian ini adalah untuk menyelidiki pengaruh beragam dari Facebook pada pola kehidupan sosial anak muda. Kedua metode pengumpulan data kuantitatif maupun kualitatif digunakan untuk mengumpulkan data. Kuisioner, jadwal wawancara, dan wawancara informan kunci adalah alat pengumpulan data yang digunakan untuk mengumpulkan baik data kuantitatif maupun kualitatif. Studi ini menemukan bahwa, Facebook adalah media sosial yang menghambat ikatan sosial dalam satu cara dan
\end{abstract}

Submitted: 2020-02-04; Accepted: 2020-04-14; Published: 2020-04-24

*Corresponding author: Email: damedereba@gmail.com 
mendorong dengan cara lain. Dengan berjejaring secara online, media ini meningkatkan afiliasi yang kuat di antara teman-teman Facebook dengan membuat mereka mengabaikan orang-orang di sekitarnya, dan melemahkan tatap muka dengan interaksi langsung. Pengguna Facebook yang tidak saling mengenal dapat bertemu di 'ruang obrolan' dan berdiskusi tentang topik pilihan mereka dengan orang lain. Jenis persahabatan dan interaksi elektronik ini dapat tumbuh dan mengarah ke kontak fisik berupa tatap muka dan perjumpaan fisik. Oleh karena itu Facebook merupakan sebuah platform bagi kaum muda untuk berdiskusi dan berinteraksi tentang berbagai hal yang dapat meningkatkan sinkronisasi antar pengguna di satu sisi dan berpotensi memunculkan konflik retorika yang meradang di sisi lain, yang menyiratkan pengaruh Facebook yang tak terhindarkan dan multidimensi di kehidupan sosial generasi muda.

Kata kunci: facebook, interaksi, kehidupan sosial

\section{INTRODUCTION}

Over the last decade daily experiences of youngsters have been transformed by developments in social media. These media are daily tools of communication, information dissemination and amusement for the majority of young people. It is timely issue to study the potential hazards and constructive contributions accompanied with the advancement of these technologies on the youngsters' social life (Boyd and Ellison 2007).

Most people accept the idea that media can influence people. But, the degree of that influence, as well as who is most-influenced and why, by which medium have been the subjects of controversy among many scholars for long. Facebook is a social medium that enables sending and receiving of messages across the world. Hence, youths have access to a lot of information. They are exposed all the time to information meant for adults or other groups in a medium inaccessible to many parents or teachers that may shape them in unforeseen traditions. Owing to its far reaching social identity impacts Facebook turn out to be a big concern (Baym, Zhang, and Lin 2004).

Sometimes, Facebook promotes a value which stand in contrast to the values entrenched in a given society's social institutions like the family, church and schools. These new values, which the Facebook appears with, are more tolerant of behaviors that are considered improper by a society (Al-Zeaud 2014; Mustofa 2019). For example, things like nude pictures and movies are apparently exchanged among Facebook friends regardless of the implication it accompanies. The exposure of teenagers to such pictures, movies and others may result in socializing them to accept those things as normal. That is why (Merten and 
Williams 2009) said 'it has become imperative for consultant to understand the role of media exposure on children in order to diagnose and treat behavioral problems as well as to prevent further tragedies'. So, Facebook has attracted much attention from parents, educators, social scientists, religious leaders and all those who are concerned with societal norms and values (Simon 2006).

On the other hand, Facebook provides an ability to communicate with people worldwide, more easily and regularly. It helps the user to send and receive messages to and from anybody in any part of the world within a matter of seconds. The growing accessibility of internet through cell phones and other devices allow people to quickly and easily increase their knowledge on a broad range of topics (Warschauer, Turbee, and Roberts 1995). Therefore, Facebook has many positive effects too if properly used. Facebook is a problem when youngsters are left to themselves in using it without adequate supervision and guidance from family and significant others. Because, Facebook is not merely a boon that leaves our youth more socially connected, rather as many voices warn it may affect the quality of face to face personal interactions (Anderson and Bushman 2001).

Behavior in young is caused by a number of factors. It is sociological fact that, culture and other social structural components are some of the factors that are behind the way the youths dress, talk, walk and act. But, in this study the influences of Facebook on youths' pattern of social life and interaction is given due attention (Hutchins 2011). Researcher has amassed a vast amount of literatures on what do researchers made about how youth use Facebook and about how that uses influences their social life. But previous investigations ayouthre scanty in numbers and academic focused. So, the main objective of this study was to assess the influences of Facebook on the youngsters' pattern of social life as youths are the future hopes of the country (Neuhaus and Webmoor 2012).

Novelty in this research is that there are various solutions for the use of Facebook and social media for the younger generation. In previous studies there were some who explained the positive position, so also there were those that produced negative effects. Facebook is a communication medium that blocks social ties in one way and pushes it in another. By making friends online, this increases strong affiliation among Facebook friends while by letting them ignore the people around them, it weakens face-to-face personal social relationships. 


\section{METHODS}

The study was conducted on high school students of Harar city. Harar city is the capital of Harari people's regional state. The city is located at a distance of $526 \mathrm{kms}$ from Addis Ababa in the eastern part of Ethiopia. Harar urban morphology presents two main parts: the ancient city and the recent one that has entrenched lately. The ancient walled city named Jugal has a high population density on an area of 62 hectares with internal differences of level ranging from 0 to 60 meters which is a root for the expansion of lately emerged city parts (Jackson and Lilleker 2011).

Harar is a spectacular city in that it is a miniature of Ethiopia as peoples belonging to different nations and nationalities live together. Based on the 2007 census conducted by the Central Statistical Agency of Ethiopia (CSA), Harar city has the total population of 99,368. Harar city is organized into six administrative districts and 19 kebeles or sub-districts. Harar city has eleven high schools out of which eight are public while three are private. From these, three of them (one private and two public) encompasses preparatory program while the rest of them are up to grade ten (Hong and Nadler 2012).

Figure 1.

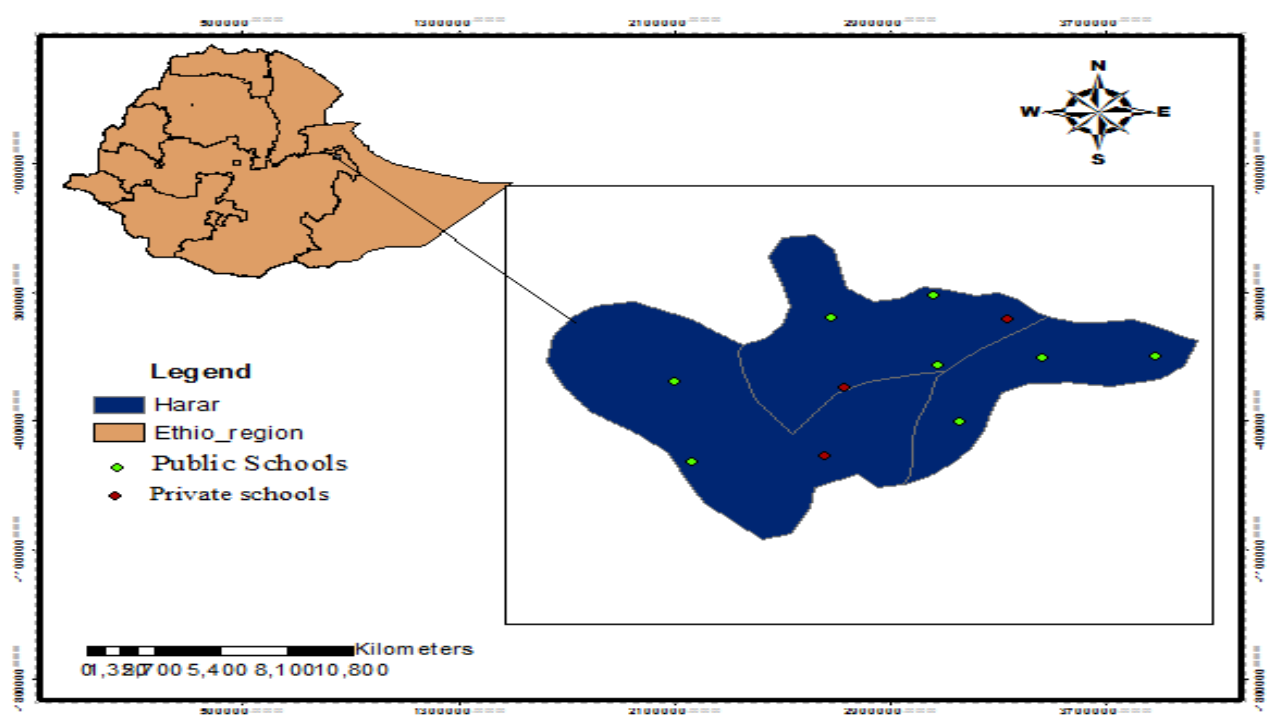

Map of the Study Area. Source: Constructed by GIS expert

This study employed a mixed (both quantitative and qualitative) research approach. The rationale behind employing mixed approach was that, when used in 
combination, quantitative and qualitative methods complement each other and allow for more complete analysis. Indeed, large size of the students coupled with the nature of the subject of study demanded both quantitative and qualitative methods of data collection (Nasution 2014).

From quantitative methods of data collection, the researcher used cross sectional survey design which helped to address large size of students through samples at a onetime contact. From qualitative methods, case study was used to collect detailed information from the well informed students about the influences of Facebook (Flad 2010).

Quantitative data were collected through questionnaire and interview schedule primarily from the selected high school students and households. Questionnaire was administered to 334 students whereas, 19 households were selected for interview schedule from different kebeles of the city (Ostrom, Tiebout, and Warren 1961). On the other hand, qualitative data were collected using key informant interviews from the well-informed students about the influences of Facebook. Three key informant interviews were made with selected students from each three high schools. Other pertinent respondents like teachers, youth officer and peers outside the school were also interviewed to the data saturation points. Secondary data were also collected by visiting Facebook profiles of some students through secondary analysis (Boyd 2007).

The target population of this study was high school students from the selected high schools of Harar city. So, mainly students who were admitted to high schools were the target of this research. There are eleven high schools (eight public and three private) in Harar city. From these, three of them (one private and two public) have preparatory programs while the rest of them are up to grade ten. The sample for this work is therefore, taken from three purposively selected high schools of the city. The main reason for selecting three high schools was that these schools are different from each other in terms of location and other related factors (Newman 2008). Some are at the center of the city where the majority of students are from the city and have parents who follow their education and some others are at the frontiers of the city where the majority of the students are from rural family backgrounds. On the other hand, some schools are under religious realm and privately owned while some others are under governmental control. The aforementioned differences have something to do with difference and similarity of 
Shoa: The Influences of Facebook on

High School Students' Pattern of Social

Life: The Case of Harar City

Facebook influences on the students of different schools which motivated the researcher to choose three different high schools out of the existing 11 high schools (Dorothy, Singer, and Jerome 2001).

Thus, Aboker High School from public schools in the center of the city, Lutheran High School from private/religious schools, and Hamaressa High School from the outskirts of the city were selected for the study.

Sample size was determined using both probability and non-probability sampling techniques. Students were startified according to their grade levels to analyze the relationship between educational status and youths' social behavior which results from Facebook influences (Achmad and Ida 2018). From each strata sample were selected randomly to see the differences of Facebook influence on different students. Attendance sheet of each class were accessed from their teachers and used to pick randomly the anticipated sample respondents. According to the 2015/16 data obtained from Harari Regional bureau, the total number of students in the selected three high schools was 2057 (Lassen and Brown 2011). From this, the sample size was computed using Slovin's formula as follows:

$\mathrm{n}=\mathrm{N}$ is the sample size determination formula from the total students (slovin's formula)

$$
\begin{gathered}
1+\mathrm{Ne}^{2} \\
\mathrm{n}=\text { Required Sample } \\
\mathrm{N}=\text { Total Population } \\
\mathrm{e}^{2}=\text { Margin of error }
\end{gathered}
$$

$\mathrm{n}=2057 / 1+2057(0.05)^{2}=334$

Sample size from each stratum was computed as follows:

$$
\begin{aligned}
\mathrm{n}_{\mathrm{k}}=\mathrm{N}_{\mathrm{k} / \mathrm{N}} \mathrm{n} \text { Where: } & \mathrm{K}=\text { is a Stratum Number } \\
& \mathrm{N}_{\mathrm{k}}=\text { is the size of Sub-Students in Stratum k, } \\
& \mathrm{n}_{\mathrm{k}}=\text { is the Sample Size for Sub-Students in Stratum k, } \\
& \mathrm{N}=\text { is the Total Number of Students in a given School }
\end{aligned}
$$

Accordingly, population size and respective sample size selected from each stratum will be presented in the table below. 
72| The Journal of Society and Media 4(1)

Table 1

\begin{tabular}{|c|c|c|c|c|c|c|c|c|c|c|}
\hline Schools & \multicolumn{5}{|c|}{$\begin{array}{l}\text { Number of Students in Each } \\
\text { School }\end{array}$} & \multicolumn{5}{|c|}{ Selected Sample Size } \\
\hline $\begin{array}{l}\text { High Schools that have } \\
\text { preparatory program }\end{array}$ & $\begin{array}{l}\text { Grad } \\
\text { e9 }\end{array}$ & $\begin{array}{l}\text { Gra } \\
\text { d10 }\end{array}$ & $\begin{array}{l}\text { Grad } \\
\text { e } 11\end{array}$ & $\begin{array}{l}\text { Gra } \\
\text { d12 }\end{array}$ & Total & $\begin{array}{l}\text { Grad } \\
9 \\
\text { sampl } \\
\text { e }\end{array}$ & $\begin{array}{l}\text { Grade1 } \\
\text { 0 } \\
\text { sample }\end{array}$ & $\begin{array}{l}\text { Grade } \\
11 \\
\text { Sampl } \\
\text { e }\end{array}$ & $\begin{array}{l}\text { Grad } \\
\text { e } \quad 12 \\
\text { samp } \\
\text { l }\end{array}$ & $\begin{array}{l}\text { Tota } \\
1\end{array}$ \\
\hline Aboker High School & 443 & 400 & 408 & 321 & $\begin{array}{l}157 \\
2\end{array}$ & 72 & 65 & 67 & 52 & 255 \\
\hline Lutheran High School & 57 & 68 & 125 & & & 9 & 11 & 20 & & \\
\hline $\begin{array}{l}\text { Hamaressa } \\
\text { School }\end{array}$ & 225 & 135 & 360 & & & 37 & 22 & 59 & & \\
\hline Total & & & 2057 & & & 334 & & & & \\
\hline
\end{tabular}

Sample Size of Each Stratum

Stratified sampling was supplemented with purposive sampling design to reach the parents of the students. The logic behind using purposive sampling technique was to collect data through interview from households having young student in their family members (Al-Dheleai and Tasir 2017). Hence, 19 households who have youth in their family members were selected purposively for the interview. That means, in the interest of time and resources only 19 households (one household from each Kebele of the city) were selected based on their knowledge of Facebook and availability of young students in the family members (Jack and Tim 2006).

Moreover, to conduct a key informant interview with the students who highly utilize Facebook, purposive sampling was used to identify the students based on prior information gathered whether they highly use or not. Then one key informant interview was conducted with one student from each school for the sake of comparative analysis between the students of different schools. Teachers, youth officers and peers were also reached through purposive sampling technique (Jannah, Handayani, Yuswadi, and Hidayat 2019).

In this study, descriptive statistics like percentage were used to analyze the collected data. Qualitative data were analyzed through preliminary exploration of 
Shoa: The Influences of Facebook on

High School Students' Pattern of Social

Life: The Case of Harar City

the data by reading through the transcripts, listening records, and writing memos; coding the data by segmenting and labeling the text; using codes to develop themes by aggregating similar codes together; connecting and interrelating themes and constructing a narration. Qualitative data analysis involved developing a detailed description of each Facebook influences. Furthermore, data were comprehensively analyzed supplementing quantitative data by the qualitative data (Perse 1998).

\section{RESULTS AND DISCUSSIONS}

Influences of Facebook on the Students' Pattern of Social Interaction. Facebook is a medium of communication that mediates communicators within a few seconds. Today, physical presence of communicators is not compulsory to convey a message to one another. Cyber contact simplified sending and receiving of messages from different corners of the world within a short period of time. Particularly, Facebook is the most popular social medium that makes two ways communications possible between friends on the issues of communicators' mutual interest. So, Facebook is influential on user's mode of interaction specifically in the society where personal bond is powerful. The following data indicates how Facebook is influencing the styles of youngsters' interaction (Mcguire 1986).

Table 2.

\begin{tabular}{lcc}
\hline Ways students appoint their friends & Frequency & Percent \\
\hline Via text message & 52 & 15.6 \\
Via-email & 9 & 2.7 \\
personal contact & 119 & 35.6 \\
Via Facebook & 66 & 19.8 \\
Via cell phone & 47 & 14.1 \\
via other social networks (eg viber) & 31 & 9.3 \\
Other means & 10 & 3.0 \\
Total & 334 & 100.0 \\
\hline
\end{tabular}

The way students arrange appointment with their friends 
As indicated in the table 2 above, $35 \%$ of the respondents used to arrange appointments with their friends through face to face personal contacts. This means, youths with less exposure to latest technology still depends heavily on face-to-face personal contacts to meet each other (Damayanti and Hidayat 2019). This does not mean that they are totally away from mediated communication rather they overwhelmingly depend on face-to-face contacts than mediated ones. Mediated communication like Facebook is a recent phenomenon that came to be practiced among some youths with the likely chance to be extensively adopted and practiced by the mass (Lazarsfeld, Merton, and Wright 1984).

Some other respondents, about $19 \%$ of them arrange appointments with their friends through Facebook chat. Chatting on Facebook is a common ways of arranging contact among the youth Facebook users. It is a fashionable style of appointing one another and conveying a message from each other (Ejaz and Javaid 2018). One student from Aboker high school stated that:

There is a Wifi area in our school no matter how slow it is. I cannot stay in class for so long since I started using Facebook, I always have the urge to go Wi-Fi area and check my Facebook and see what others are doing. I say to myself, you can take a break; check what is happening around; and chat for a while if friends are online. I feel always the urge to check Facebook, especially when I am depressed. I get relief when I talk to friends on Facebook.

From the above statement, one can understand that the availability of WiFi area in Aboker preparatory school is a contributing factor to students' use of Facebook anytime they need. The availability of internet connection attracts youngsters to recurrently visit their Facebook and exchange ideas on the issues of their choices. People scape stress by keeping in touch with friends online. Facebook is entertaining for youth to bear with it. It is used to exchange any messages whether personal or official with freedom. Facebook is a means by which youth's update themselves with info of their friends via chat. Chatting on Facebook is therefore, the most purpose Facebook is utilized among some youths in the study setting. So, it is a potential challenge to face-to-face personal interactions.

On the other hand, about $14 \%$ of the respondents indicated that they depend on phone call and texts to arrange meeting with their friends. Only few percentages of the respondents indicated that they depend on email and other 
Shoa: The Influences of Facebook on

High School Students' Pattern of Social

Life: The Case of Harar City

means of communication to arrange meetings with their friends. The remaining $9 \%$ of the respondents use other social networking media like viber, imo, whats up, twitter, skype and so forth which verify Facebook as a giant social medium that is playing a dominant role in youngsters' social network (Moura and Michelsen 2017).

Relationship with others is at the heart of adolescent experience. Young people are concerned with making and keeping friends, and they invest a great deal of endeavor in group life in order to do so. They place a lot of importance on belonging, on being included and on being part of a group. Thus group context of social relations assumes a centrally important place in personality development during the adolescent stage. Below data reveals how the students enhance friendship with the support of Facebook (Meilinda 2018).

Table 3

\begin{tabular}{cll}
\hline Use Facebook to enhance inter-friend relationships & Frequency & Percent \\
\hline Yes & 102 & 30.5 \\
No & 141 & 42.2 \\
Don't use Facebook at all & 91 & 27.2 \\
Total & 334 & 100.0 \\
\hline
\end{tabular}

Use Facebook for the enhancement of inter-friend relationship

As table 3 above shows, $30 \%$ of the respondents use Facebook to enhance entrenched good relationships with friends. One respondent reported that:

I am not sure; sometimes I stay online for a long period of time. Even there is a time I stay online throughout the day. It is not planned rather depends on the mood. I remember the time spontaneously started chatting and stayed on it for long hours without even being concious about the time duration. While doing something on Facebook other activities had to be put on hold. I do not give the chance for my friends and family members to interrupt once I started chatting on Facebook.

Any Facebook users can talk textually or by sound online with the help of digital technology. It is possible to talk to anybody that one does not know before on Facebook and this type of electronic friendship and interaction may grow up and lead to virtual physical face-to-face contact. Youths can discuss on the issues 
of their mutual interest meeting each other on Facebook chat rooms. Facebook enhances personal relationship by bringing different individuals together who does not know each other before. This argument corresponds with (Siibak 2009) sociological view of internet positive contribution that internet fosters new forms of electronic relationship that either enhances or supplements existing face-to-face personal relationships. While moved away from family for education or work, travelling outside the country; or working abroad; individuals can use Facebook to communicate regularly with friends and relatives. Distance and separation become more tolerable. Perhaps Facebook allows for the formation of new types of relationship: 'anonymous' Facebook users can meet in 'chat rooms' and discuss on topics of their choice. These cyber contacts sometimes evolve into full-fledged electronic friendships or even results in face-to-face contacts in long run (Linz and Malamuth 1993).

The above quoted data implies that the spread of Facebook could lead to increased social isolation and individualization. There is a fear that one effect of increasing Facebook access in household is that people are spending less 'quality time' with their families and friends. Human contact would be reduced, personal relationships suffer, traditional forms of entertainment such as the theatre and books fall by the wayside, and the fabric of social life would be weakened. This would raise challenging questions about personal identity.

So, Facebook debilitates partly intimate human relationships and communal lives. The more time youths spend on Facebook, the less time they spend with peers and families in the physical world. As a result, youngsters would not be able to communicate and socialize effectively in person with others. Families are getting more and more unsatisfied with the social skills of the youths as Facebook is pacifying users from consuming their time to learn actual life experiences in the real world. Because, as people spend more and more time communicating online and handling their daily tasks in cyberspace, they may spend less time interacting with one another in the physical world (Eveland, Mcleod, and Signorielli 1995).

So, Facebook is a medium of communication that discourages social bond in one way and encourage in the other way. By networking peers online, it encourages strong linkage among Facebook friends while by letting them ignore 
people who are nearby, it discourages intimate face to face social relationships (Shahzad 2013).

Influences of Facebook on students social (group) life. Facebook is not only medium of communication, rather a means of creating group and online communities. People organize themselves with the name that best describe their group and feel oneness to each other. They used to share events of life whether happiness or sadness on Facebook. The following table describes students' membership to different Facebook groups.

Table 4

\begin{tabular}{crr}
\hline Member of any Facebook group & Frequency & Percent \\
\hline Yes & 188 & 56.3 \\
No & 62 & 18.6 \\
Don't use Facebook & 84 & 25.1 \\
Total & 334 & 100.0 \\
\hline
\end{tabular}

\section{Facebook group membership}

As stated in the table 4 above, more than half the respondents belong to different groups on Facebook. This means, an individual Facebook user may create initially online groups that significant others whom name given for the group best describes join and become group members or join already created groups (Abramowitz and Webster 2016). One of the respondents responded that:

I am a member of Facebook groups such as Harar lijoch, Arsenal group, orthodox tewahido lijoch, yemariayam lijoch, Aboker high school, funny group, and others that I can't remember now. I receive different information from these group networks. I reflect my support to my group and opposition or loathing to counter groups by liking, commenting, sharing, blocking and posting on these groups' pages.

The above data reveals that a youth tied by Facebook network develops a sense of oneness and belongingness towards each other. They share and exchange messages that best describes their groups than individual. Therefore, we can understand from this that Facebook is one means of alliance and creating team spirit among the youth users. It contributes a lot to the strengthening of social networks (Huff 2001). 
On the other way, Facebook is a scapegoat for the creation of aversion between different groups through posting the messages that reflects hatred towards one another. In this context Facebook is a platform to strengthen the solidarity among particular Facebook group members in their opposition against the opponents. For instance, researcher came across "orthodox group" versus "Protestant group" during secondary data analyses which were created to forward contentious ideas against each other. Plenty of analogous groups are there to intensify debates, disagreements and virtual conflicts between different groups. Despite its advantage of creating unity among one group members, Facebook can leads to protracted discontents between members of different groups. In fact, Facebook is serving as a new form of online social interaction in one way or another, as conflict is also one-way people act and react towards each other beyond peaceful exchanges. So, Facebook is a latest medium of communication that may either enhance or constrain social cohesion among and between different groups (Greenberg 1993).

Beyond that, review of some students' Facebook profile reveals that, youths create different groups for different purposes. For instance, entertainment group, educational group, high school group, love group, funny group and so forth are some of the groups' prototype formulated on Facebook. Youths belonging to those groups receive respective messages of group intention that may entertain, teaches or affects the youth in another way. Youths belonging to the above groups are more likely to tilt towards nature of the group behaviorally. Membership to Facebook group may increase exposure of youths to adult behavior, because the groups may compose peoples of different ages particularly adult and interaction among the group leads to the exchange of deviant behavior and other wisdom they have.

It seems what everything is inseparable from latest technology like Facebook in this globalized world as the formation of group, cooperation among people and conflict on the other side, are all practiced on Facebook. That is a big frustration and phobia of conservative people as Facebook is intruding in every aspect of social life. The following table shows the increasing problems of Facebook harassments among the users (Ram 2015). 
Shoa: The Influences of Facebook on

High School Students' Pattern of Social

Life: The Case of Harar City

Table 5

\begin{tabular}{crr}
\hline Do you think there is bullying on Facebook? & Frequency & Percent \\
\hline Yes & 172 & 51.5 \\
No & 162 & 48.5 \\
Total & 334 & 100.0 \\
\hline
\end{tabular}

Electronic harassment

Table 5 above shows that electronic harassment is an increasing problem on Facebook for half of the respondents participated in this research. This means, Facebook is not only a means of peaceful interaction rather a means of conflict manifestation between users (Singh 2014). One of the informants said that:

An individual quarreled with others write a text, upload photos/movies or any other messages that describe his/her feeling towards the counter group. By using a false name or by using others' name, it is possible to talk and exchange ideas with new or familiar friends. Sometimes the manipulated photos of politicians are posted fused with the pictures of donkeys, dogs and other animals using technological edition (photo shopping) on Facebook. Facebook is among the devices youths used to campaign against the government.

Action and counter reaction that leads to interaction between Facebook friends could be positive or negative. Positively, youths discuss and interact on the issues of mutual curiosity which could enhance and promote synchronization of friends. Negatively, some other youths use Facebook to express their disgust towards each other. Post of repugnant messages against politician, celebrities and famous people is a vivid witness of harassments perpetrated on Facebook (Rose 1998). It is also evident to see mobilization and movements made by high school students through Facebook against the government and the existing system. For example, in 2016 movement against the Ethiopian government, youngsters were the forefront and active participants of the Facebook mobilization. It came to be a new form of movement against a system that is considered inept. So, it is possible to describe Facebook as inflammatory rhetoric weapon, means of revolution and 
harassment in this $21^{\text {st }}$ century. This implies that Facebook is a great tool in promoting unity among people sharing mutual goals (Spykman 1938).

Socialization influences of Facebook on youngsters. Youths demand close supervision from parents on technology utilization to reduce unnecessary exposure to violent portrayals. Free accessibility of different information on Facebook may make the students vulnerable to antisocial practices portrayal. The following table shows type of messages students upload on and download from Facebook and how these messages influence their socialization aspects.

Table 6

\begin{tabular}{lcc}
\hline Information students upload on and download from Facebook & Frequency & Percent \\
\hline Sports message & 6 & 1.8 \\
Mini movies & 2 & 0.6 \\
Music & 26 & 3.8 \\
small texts & 11 & 3.3 \\
Films & 11 & 3.3 \\
Spiritual pictures & 35 & 7.9 \\
New happenings & 9 & 2.7 \\
Photos & 74 & 22.2 \\
Romantic and sexual messages & 43 & 20.8 \\
political news & 3 & .9 \\
All & 15 & 2.9 \\
Other messages & 8 & 2.4 \\
I don't use Facebook & 91 & 27.2 \\
Total & 334 & 100.0 \\
\hline
\end{tabular}

Information students upload on and download from Facebook

Table 6 above demonstrates the distribution of respondents based on the information they upload on and download from Facebook. It discloses that majority of the respondents upload and downloads photos on and from Facebook. Uploading photos on once own Facebook page is a common practice youths undergo to receive like and comments from their Facebook friends. One informant stated that: 
Shoa: The Influences of Facebook on

High School Students' Pattern of Social

Life: The Case of Harar City

Emerging youngsters are busy with decorating photos on Facebook. Youth overemphasis' colorful things like film celebrities, models and the successful men and women in the fields of sports, athletics, business, and politics, well adored and nude pictures, mini movies, music and other glamour things.

As it is already indicated, photos uploaded on Facebook are mostly decorated photos that attract the attention of viewers. Particularly, some photos are very inflammatory to the viewer's due to their adornments and nudity natures. Teenagers spent a lot of time on preparing those photos, by making photo shops, editing photos and making ready for the uploads. Students waste their study time by taking photos every now and then and decorating them. Taking photos become mundane practices with different styles while eating, studying, and walking, in the school and elsewhere. It is not only time that students waste in making photos but they also contribute to the initiation of unnecessary and untimely sexual desires as the photos/pictures are nude and provocative by their appearance. Hence, Facebook often hypes the basic facts or information and presents them so as to increase the superficial appeal of things. As a result, socio-cultural values that Facebook supports and which are taking root in society in modern times are superficial and oriented towards glamour. Traditional social wisdom of strong social intimacy, cooperation, philanthropic outlook and religious value are being declining due to Facebook influences.

Romantic and sexual messages are another thing that youths used to upload on and download from Facebook. A considerable number of respondents (20\%) responded that they upload and download romantic and sexual messages. It is enthusiasm for the youth to upload and see romantic picture and movies on Facebook. As one informant stated:

Many youngsters who see sexual related messages initially feel shame, diminished self-confidence, and sexual uncertainty, but these feelings quickly shift to unadulterated enjoyment with regular viewing. They became eventually habited to view and practice what others do on Facebook by imitation. I feel this happen due to parents' carelessness and absence of sexual education since childhood.

The above statements reveal that youths lack sexual education and hence exposure to sexual matters makes them very eager to know about it. The problem prevails in the contradiction of what is seen on Facebook and what is practiced in 
the society. Facebook gives youths with the freedom to see, read, like, comment, share romantic picture and movies while local environment denies. So, youths observe a contradiction between conservative local milieu and modern medium like Facebook as what they collected from family and religious institution contradicts with what they see on Facebook. Thus exposure to Facebook can easily influence the youth to learn and become victims of experiences they were not accustomed to before their exposure such as sexual behavior and values that are bigotry in the study society (Maliha 2018).

Cybersex is highly addictive and can lead the youth to sexually compulsive behaviors that decrease their capacity to perform other social tasks. Researcher asked the marital status of some respondents that is filed on their Facebook profile and two of them responded that, "in open relationship, and complicated relationships" respectively. An individual habited to multi sexual partner faces the difficulty of limiting oneself to a single marriage partner. Thus, social value of marriage and family establishment like procreation declines for such youths (Demaray, Malecki, Davidson, Hodgson, and Rebus 2005).

Some other respondents upload and download information like mini movies, music, small texts, films and so forth, whereas few others upload and download spiritual pictures, sports, personal address and other related messages. The problem with this is that it can become a traumatic experience especially with the young, as they see it more and more. Adolescents that are starting to grow and are shaping their personality, values and beliefs can lose a sense of reality on the ground (Feshbach 1972).

Some are fascinated towards entertaining messages like music, films and movies to spend their leisure time. Despite some youths are yet under the realm of family and religious influences and mood their Facebook utilization accordingly, some others are still using to upload and download violent messages that would result in typical behavior and non-normative social acts (Kabre and Brown 2011).

Coupled with the aforementioned scenario, the main problem of today's society is the growing role of family carelessness to look after immature youngsters as indicated in the above quoted data. Despite their reluctance, parents have many opportunities to influence how their children need to use Facebook. Messaris, (1986) pointed out that parents can mold their children's interpretation of media program through discussion while viewing or listening. Parents can help 
Shoa: The Influences of Facebook on

High School Students' Pattern of Social

Life: The Case of Harar City

children learn about the conventions of the medium and distinguish fact from fantasy (Princenton 2008).

On the other way, Facebook is a platform on which social and political matter is discussed and political events are played out which in turn provides political and other aspects of socialization to adolescents. For most, politics is unobtrusive and experienced indirectly through the report of medium like Facebook. Through its surveillance function, Facebook reports on political matters. It is a tool that peoples use to challenge politicians by disclosing its secret to the wider public. Below data reveals how political activists' use Facebook for political participation:

By using a false name or assuming someone else's it is possible to talk and exchange political ideas with new or familiar friends on Facebook. Some others post the photos of politicians combining with donkey, dog and other animals using technological edition to express their feeling, acceptance and resistance towards the work of government agents.

There is a condition where Facebook is meant for political campaign. Youngsters feel free to anonymously write about politicians and political systems on Facebook. Government agents can also get feedback from peoples through what is posted on Facebook. Facebook provides youth with the chance to participate in politics. This implies that the influence of Facebook medium in fostering youth's political behavior is greater than family institution in today's society (Damanik 2018).

How Often Students Use Facebook While Engaging in Other Social Activities? Facebook is a social medium frequently used to update oneself with latest information of this social world. It is possible to check what is new on Facebook simultaneously while doing other things. The following data reveals how often students use Facebook while doing another social activity (Toker and Baturay 2019). 
84 I The Journal of Society and Media 4(1)

Table 7

\begin{tabular}{lccc}
\hline $\begin{array}{l}\text { Time often students are on Facebook while doing another } \\
\text { activities }\end{array}$ & Frequency & Percent \\
\hline Mostly & 16 & 4.8 \\
Sometimes & 141 & 42.2 \\
Conditionally & 19 & 5.7 \\
once per a day & 21 & 6.3 \\
every time & 12 & 3.6 \\
Never & 37 & 11.1 \\
Not available & 88 & 26.3 \\
Total & 334 & 100.0 \\
\hline
\end{tabular}

Regularity that students open facebok

As revealed in the table 7 above, majority of the students (about $42 \%$ ) engage sometimes in surfing Facebook while doing other activities. Students log into their Facebook account and check what is there online while eating, attending the class, doing homework, studying or doing any other things. In this regards, Facebook is interrupting the concentration of students studying and distract them from their academic and other works. Because, their energy is wasted on different tasks and not focused on one single task, their performance thus is affected. Facebook impacts the performance of users by increasing their multitasking levels and by breaking their focus and engagements. It allows them to put off studying while not giving them the feeling that they are not working. One student reported that:

There is a Wifi in our school no matter how it is sometimes slow. Students return to home after the class go back to the school to use library or to do homework with friends, though after a while they say to themselves let me visit wifi zone once and check what is there on Facebook, but remain there throughout the day while chatting and doing other things with their Facebook friends.

Consistently the other student said that,

I cannot study for long periods of time anymore, especially now when I use Facebook, I always have this urge to go and check my Facebook and see what others are doing. I say to myself, you can take a break, check what's happening around, I'm not sure if it has a negative effect on my study but I feel always the urge to check Facebook, especially when I'm studying. 
Shoa: The Influences of Facebook on

High School Students' Pattern of Social

Life: The Case of Harar City

From this one can imply that, youths are addicted and urged by their habit to open and check what friends are doing on Facebook. Facebook is addictive, because it offers at all points, the possibility of finding out something that someone is saying about others. Once youths get into the habit of seeking this distraction when temporarily bored, their ability to concentrate during other times will be reduced. One respondent stated that "if I start checking Facebook during my unoccupied time, I'm influenced that the overall quality and quantity of time I can spend doing things like solving proofs, will begin to decrease". This means addiction to Facebook pacifies the users by displacing their social skills. The idea that one can restrict their access to this addictive service to only downtime is innocent. Because, Facebook checking soon pervades all areas of their life, including those times in a pre-Facebook era; they would be interacting with family or friends. Hence, habituation to Facebook affects the students' potential as it is distributed to different tasks that reduce their concentration on selected activities at one time (Omolayo, Balogun, and Omole 2013).

\section{CONCLUSIONS}

This study addressed the social influences of Facebook on high school students of Harar city. From the study findings, the researcher concluded that everyday exposure to Facebook competes and challenges the time dedicated for other social activities. It takes the place of face to face discussion and interaction with peers that leads to eventual social isolation and individualization. Facebook is intruding in the fabrics of social life in reducing the quality and quantity of face to face personal interaction. This leads to stunted social development. On the other side, Facebook strengthens a social network among youths living apart from each other's. It enhances personal relationship by bringing different individuals together. Facebook is a fashionable style of appointing one another and conveying a message from each another. It is entertaining and addictive for the youth to bear with Facebook. Facebook is alternative means of social interaction among online friends or groups. It allows for the formation of new types of relationships. Anonymous Facebook users can meet in 'chat rooms' and discuss on topics of their choices with the person they do not know before and this type of electronic friendship and interaction may grow up and leads to virtual physical face-to-face 
contacts. Hence, it enhances online social networks and limits face to face personal interaction.

Facebook is a platform for youths to discuss and interact on the issues of mutual curiosity which could enhance and promote synchronization of friends on the one side and inflammatory rhetoric conflicts on the other side. The study also came up with the conclusion that using Facebook enables youngsters to socialize themselves by their own with less influences of family and religious institutions. Facebook often hypes the basic facts or information and presents them so as to increase the superficial appeal of things. Socio-cultural values that Facebook supports and which are taking root in today's society is superficial and oriented towards money and glamour. Youths exposed to such Facebook contents can easily imitate and mold their behaviors accordingly. Facebook can easily influence the youth to learn and become victims of experiences that they were not accustomed to before their exposure such as 'deviant sexual behavior' and values that are not tolerable in the study society. It also provides youth with the chance to participate in politics. Youngsters feel free to confidentially write about politicians and political systems on Facebook. Therefore, it is possible to say that Facebook influences on youth's social life is multidimensional and inevitable. Based on conclusions, researcher suggested the following recommendations to promote the positive influences and to reduce the negative influences of Facebook on youngsters' social life.

\section{REFERENCES}

Abramowitz, A. I., and S. Webster. 2016. "The Rise of Negative Partisanship and the Nationalization of U.S. Elections in the 21st Century." Elect. Stud. $41: 12-22$.

Achmad, Zainal Abidin, and Rachma Ida. 2018. "Etnografi Virtual Sebagai Teknik Pengumpulan Data Dan Metode Penelitian." The Journal of Society and Media 2(2):130-45.

Al-Dheleai, Yahya M., and Zaidatun Tasir. 2017. "Using Facebook for the Purpose of Students' Interaction and Its Correlation with Students' Academic Performance." Turkish Online Journal of Educational Technology - TOJET 16(4):170-78.

Al-Zeaud, H. A. 2014. "Public Debt and Economic Growth: An Empirical 
Shoa: The Influences of Facebook on

High School Students' Pattern of Social

Life: The Case of Harar City

Assessment.” European Scientific Journal 10(4):148-58.

Anderson, C. A., and B. J. Bushman. 2001. "Effects of Violent Video Games on Aggressive Behavior, Aggressive Cognition, Aggressive Affect, Physiological Arousal, and Pro-Social Behavior.A Meta-Analytic Review of the Scientific Literature." Psychological Science 12:353-59.

Baym, N.K, Y.B. Zhang, and M. Lin. 2004. "Social Interactions across Media: Interpersonal Communication on the Internet, Face-to-Face, and the Telephone." New Media \& Society Vol. 6(3):299-318.

Boyd, D. 2007. Why Youth (Heart) Social Network Sites: The Role of Networked Publics in Teenage Social Life. Cambridge: MA, MIT Press.

Boyd, D., and N. Ellison. 2007. "Social Network Sites: Definition, History, and Scholarship." Journal of Computer Mediated Communication 13(1):111.

Damanik, Erond L. 2018. "Whatsapp Dan Pemilih Pemula Di Kota Medan: Partisipasi Politik Era Demokrasi Digital Pada Pemilihan Gubernur. Provinsi Sumatera Utara 2018.” The Journal of Society and Media 2(2):81-108.

Damayanti, Nur Laili, and Medhy Aginta Hidayat. 2019. "Hiperreality Of Social Media: A Phenomenology Study of Self Confession of Housewives of Facebook Users." The Journal of Society and Media 3(2):261-77.

Demaray, M. K., Christine Kerres Malecki, Lisa M. Davidson, Kelly K. Hodgson, , and P. Jacob Rebus. 2005. "The Relationship between Social Support and Student Adjustment: A Longitudinal Analysis." Psychology in Schools 42(7):691-706.

Dorothy, G., Singer, and L. S. Jerome. 2001. Handbook of Children and the Media, Illustrated, Reprint, Revised, Sage Publications.

Ejaz, Khushboo, and Umbreen Javaid. 2018. "U.S. Indo Pacific Policy: Response of Regional State.” Journal of Political Studies 25(2):157-75.

Eveland, William P. Mcleod, E., Douglas M. Mcleod and Nancy Signorielli. 1995. "Actual and Perceived U.S. Public Opinion: The Spiral of Silence during Persian Gulf War." International Journal of Public Opinion Research 7:91-109.

Feshbach, S. 1972. Reality and Fantasy in Filmed Violence. edited by J. P. Murray, E. A. Rubinstein, and G. A. Comstock. Television and social behavior, Television and social learning Rockville, MD: National institute of mental health.

Flad, K. 2010. The Influence of Social Networking Participation on Student Academic Performance Across Gender Lines. 
Greenberg, J. 1993. Content Trend in Media Sex. edited by D. Zillmann, J. Bryant, and A. C. Huston. Hillsdale, NJ: Lawrence Erlbaum Associates.

Hong, S., and D. Nadler. 2012. "Which Candidates Do the Public Discuss Online in an Election Campaign?: The Use of Social Media by 2012 Presidential Candidates and Its Impact on Candidate Salience." Gov. Inf. Q 29(4):455-61.

Huff, J. L. 2001. "Parental Attachment, Reverse Culture Shock, Perceived Social Support, and College Adjustment of Missionary Children." Journal of Psychology and Theology 29(3):246-64.

Hutchins, B. 2011. "The Acceleration of Media Sports Culture: Twitter, Telepresence and Online Messaging." Information, Communication \& Society 14(2):237-57.

Jack, G., and W. Tim. 2006. Who Controls the Internet? Illusions of a Borderless World. Oxford University Press.

Jackson, N., and D. Lilleker. 2011. "Microblogging, Constituency Service and Impression Management: UK MPs and the Use of Twitter." The Journal of Legislative Studies 17:86-105.

Jannah, Raudlatul, Baiq Lily Handayani, Hary Yuswadi, and Nurul Hidayat. 2019. "Knowledge Construction In Ecological Sustainability Of The Women." The Journal of Society and Media 3(2):196-215.

Kabre, Faycal, and Ulysses J. Brown. 2011. "The Influence of Facebook Usage on the Academic Performance and the Quality of Life of College Students." Journal of Media and Communication Studies 3(4):144-50.

Lassen, D., and A. Brown. 2011. "Twitter: The Electoral Connection?" Social Science Computer Review 29(4):419-36.

Lazarsfeld, F., K. Merton, and M. Wright. 1984. Mass Communication, Popular Test and Organized Social Action. edited by L. Bryson. New York: Harper.

Linz, D., and N. Malamuth. 1993. Pornography. Newbury Park: CA: Sage publication.

Maliha, Novi Fitia. 2018. "Pengaruh Media Sosial Pada Gernaha Bulan Super Blue Blood Moon." The Journal of Society and Media 2(1):1-12.

Mcguire, W. J. 1986. The Myth of Massive Media Impacts: Savaging and Salvaging. edited by G. Comstock. Orlando, FL: academic press.

Meilinda, Nurly. 2018. "Social Media On Campus: Studi Peran Media Sosial Sebagai Media Penyebaran Informasi Akademik Pada Mahasiswa Di Program Studi Ilmu Komunikasi FISIP UNSRI." The Journal of Society and Media 2(1):53-64.

Merten, M., and A. Williams. 2009. “Adolescents' Online Social Networking 
Shoa: The Influences of Facebook on

High School Students' Pattern of Social

Life: The Case of Harar City

Following the Death of a Peer." Journal of Adolescent Research 24:67-90.

Moura, M., and M. Michelsen. 2017. "WhatsApp in Brazil: Mobilising Voters through Door-to-Door and Personal Messages." Internet Policy Review 6(4).

Mustofa. 2019. "Undisciplined Reviewed From the Habitus Pierre Bourdieu Theory." The Journal of Society and Media 3(2):142-58.

Nasution, I. K. 2014. "Ethnicity, Democracy and Decentralization: Explaining the Ethnic Political Participation of Direct Election in Medan 2010." Procedia Environ. Sci. 20:496-505.

Neuhaus, F., and T. Webmoor. 2012. "Agile Ethics for Massified Research and Visualization", Information, Communication \& Society." 15(1):43-65.

Newman, B. 2008. "The Merging of Public Relations and Political Marketing." $J$. Polit. Mark. 1(2-3):1-7.

Omolayo, Benjamin O., Shyngle K. Balogun, and Olajumake C. Omole. 2013. "Influence Of Exposure To Facebook On Self-Esteem." European Scientific Journal 9(11):148-59.

Ostrom, Vincent, Charles M. Tiebout, and Robert O. Warren. 1961. "The Organization of Government in Metropolitan Areas: A Theoretical InQuiry." American Political Science Review 44(4):831-42.

Perse, M. 1998. "Implication of Cognitive and Effective Involvement for Channel Changing." Journal of Communication 48(3):49-68.

Princenton, B. 2008. "The Future of Children." Journal Issue, Children and Electronic Media,A Collaboration of The Woodrow Wilson School of Public and International Affairs at Princeton University and The Brookings Institution 18.

Ram, Vignesh. 2015. "The Proposal for an Indo-Pacific Treaty of Friendship and Cooperation: A Critical Reassessment.” Journal of ASEAN Studies 3(1):2231.

Rose, Gideon. 1998. "Neoclassical Realism and Theories of Foreign Policy." Journal of World Politicss 51(2):144-72.

Shahzad, K. 2013. "Impact of Social Networking Websites on Students, City University of Science and Information Technology Peshawar Pakistan." Abasyn Journal of Social Sciences 5(2).

Siibak, A. 2009. "Constructing the Self through the Photo Selection-Visual Impression Management on Social Networking Websites." Journal of Psychological Research on Cyberspace 3(1):1-6. 
Simon, Gebremedhin. 2006. African Media Development Initiative, Ethiopia. London WC2B 4PH UK: the BBC World Service Trust.

Singh, Sanjay. 2014. "Indo Pacific: A Construct for Peace and Stability." Indian Foreign Affairs Jurnal 9(2).

Spykman, Nicholas J. 1938. "Geography and Foreign Policy." The American Political Science Review 32(1).

Toker, Sacip, and Meltem Huri Baturay. 2019. "What Foresees College Students' Tendency to Use Facebook for Diverse Educational Purposes?” International Journal of Educational Technology in Higher Education 16(9):1-5.

Warschauer, M., L. Turbee, and B. Roberts. 1995. "Virtual Connections: Online Activities and Projects for Networking Language Learners. Honolulu: University of Hawai'i, Second Language Teaching and Curriculum Center, 1996. Comparing Face-to-Face and Electronic Communication in the Second Language Classro.” Calico Journal 13(2):7-26. 